\title{
Blending Participation Classroom Teaching to Improve Medical Students' Practical Innovation Ability
}

\author{
Jun Li, Wei Li, Ke Wang, Qianrong Liu, Lu Wang \\ Medical College \\ Hubei University of Arts and Science \\ Xiangyang City, Hubei Province, 441053, China
}

\begin{abstract}
Explore the role of blending participation classroom teaching in improving medical students' practical innovation ability by using blending participation classroom teaching. Take the courses of Preventive Medicine and Social Medicine learned by students majoring in clinical medicine and nursing in a medical college as the research object. Problem-based Learning (PBL), participation learning, flipping classroom, "Thousand questions Plan" and other blending participation teaching methods were adopted, and the implementation effect was investigated by questionnaire and the effect of students' practical innovation was analyzed. The results showed that $72.7 \%$ of the students were in favor of the blending participation teaching reform, which improved autonomous learning ability, communication ability, team cooperation ability, etc. Remarkable results had been achieved in the innovation of extracurricular practice. There are two provincial and three school-level innovative entrepreneurship training programs gained by approved university students. We have also won the third prize and two winning prize in the National Forum on Innovation in Basic Medicine and the Experimental Design Competition. Moreover, we have also won the first prize and the second prize also won third prize fifth times in the Science and Technology Competition of the Challenge Cup. We published four papers and won one national utility model patent. The blending participation teaching which combines PBL learning, participation learning, flipping classroom and "Thousand questions Plan" can effectively improve the practical innovation ability of medical students.
\end{abstract}

Keywords-Blending participation teaching; Practical innovation ability; Problem-based Learning (PBL); Flipping the classroom and thousand questions plan

\section{INTRODUCTION}

The opinions of the Ministry of Education on Speeding up the Construction of High-level Undergraduate Education to Improve the Ability of Cultivating Talents in An All-round Way (Jiao Gao [2018] No. 2) put forward that it is necessary to deepen the teaching reform, promote the classroom teaching revolution, deepen the reform of innovative entrepreneurship education and improve the comprehensive quality of students around arousing students' interest and potential in learning. As an innovative teaching method, participation teaching method can stimulate students' learning motivation and cultivate

Fund project: Research on "four-in-one" talent training system based on Clinical Medical Specialty Certification. Provincial teaching and research project of Hubei colleges and universities (2017421), key project of teaching and research of Hubei University of Arts and Sciences (JY2017009). students' innovative spirit and practical ability. It is an effective way to improve teaching effect and teaching quality and cultivate innovative talents. At present, most of the participants teaching adopt the traditional formal methods such as PPT lecture, classroom question and answer, classroom discussion and so on. The research on blending participation classroom teaching, which combines modern teaching methods such as MOOC, flipping classroom with traditional participation teaching, has not yet been reported.

Through the research and practice of Preventive Medicine and Social Medicine courses for students majoring in clinical medicine and nursing in a medical college for 7 years, such as Problem-based Learning (PBL), participation learning, online learning, flipping classroom, "Thousand questions Plan" and so on, this study constantly improved the design and practical application of blending participation teaching, and improved the classroom teaching effect. This paper probed into the implementation path and method of blending participation teaching to improve students' practical innovation ability and to provide scientific reference for carrying out classroom teaching revolution and improving medical students' practical innovation ability in an all-round way.

\section{RESEARCH OBJECT AND CONTENT}

\section{A. Research object}

In a medical college, 872 students majoring in clinical medicine in grade 2011 to 2017, 872 students in 7 grades, were enrolled in Preventive Medicine and Social Medicine, and 503 students majoring in nursing in grade 2012 to 2017, and 503 students majoring in nursing in 6 grades, were enrolled in Preventive Medicine.

\section{B. Implementation of curriculum content}

1) Preventive medicine contents

Clinical preventive services, reasonable nutritional guidance, prevention and control of infectious diseases, environment-related diseases and prevention and control, occupational-related diseases and occupational health services, food safety and foodborne diseases, hospital safety management, public health emergencies and their emergency strategies, health system and health system reform in China, 
medical insurance and medical cost control, prevention and management of chronic non-communicable diseases.

\section{2) Social medical contents}

There are social factors and health, behavioral and psychological factors and health, social medical research methods, health service research, health risk factors evaluation, life quality evaluation, social health status and health strategy, health services of vulnerable groups, social diseases and prevention and control.

\section{BlENDING PARTICIPATION TEACHING FORM}

\section{A. Division classroom participation teaching form}

In the first class, the teacher can introduce the learning goals of each chapter, and the students can participate for 40 minutes. Moreover, the second class teachers can teach and discuss the learning goals and difficulties for 45 minutes. In the first class, teachers can introduce the blending participation teaching arrangement, including the number of teaching hours, chapters, participation methods and requirements, assessment forms, etc.; further, the students were divided into groups (5 persons per group), and each group responsible for a chapter content, students need to carry out the corresponding chapter of autonomous learning before class, which can take the form of self-study teaching materials, literature reference and so on. Teachers and students can participate together and give students full autonomy according to the way of participation provided by teachers, or students can design the way of participation independently.

\section{1) Participation lecture}

Each group of students can consult the literature, carry out group discussion, make slide, send one or three representatives to teach in the classroom, interact with each other, ask questions and discuss, comment on the same group of students after teaching, point out the advantages and disadvantages, and finally the teacher carries on the summary comment.

\section{2) Play show}

According to the content of the assigned chapter, each group of students can design their own script, assign roles, role-playing in the form of teamwork, scene drama performances and so on, including air pollution focus interview, emergency simulation of public health emergencies, community follow-up and health education for chronic disease prevention and control.

\section{B. Flipping classroom participation teaching}

Each class selects a group of students to study through a certain chapter of Massive Open Online Courses (MOOC), and the group leader reports on the study, raise questions and organizes the students to discuss in class.

\section{The Thousand Question Plan participation teaching}

Social Medicine course arranged students to study themselves in combination with the corresponding chapters. Each student puts forward a question, summarizes and discusses it in the group, and designs a case in which the student representative reports, questions and discusses in class.

\section{PBL participation teaching}

PBL teaching was adopted in the prevention and control of chronic non-communicable diseases and its related chapters (health behavior intervention, tobacco control, promotion of physical activity, early detection and treatment of diseases), divided into groups (about fourteen people in each group). There are totally 6 school hours, including design cases, case discussion, asking questions, role-playing, further revision of questions, drawing chronic disease influencing factors and prevention and control chart, teacher-student feedback mutual evaluation, PPT report reply and so on.

\section{EVALUATION AND ACHIEVEMENT OF IMPLEMENTATION EFFECT}

\section{A. Questionnaire analysis of implementation effect}

In 2018, a cluster sampling method was used to evaluate the effect of blending participation in clinical medicine of grade 2016. There were 187 valid questionnaires, and the response rate was $98.4 \%$ seen in Table 1 . The results showed that $72.7 \%$ of the students were in favor of blending participation teaching, which was the favorite teaching method of students (49.2\%). It effectively improved students' autonomous learning ability (51.9\%), teamwork ability (49.7\%), communication ability (47.1\%), problem-solving ability (51.3\%), extracurricular practical innovation ability (48.1\%), etc. It can improve students' mastery of knowledge and academic performance.

TABLE I. QUESTIONNAIRE ANALYSIS ON THE EFFECT OF BLENDING PARTICIPATION IN CLINICAL MEDICINE TEACHING FOR GRADE 2016 CLINICAL MEDICAL STUDENTS $(\mathrm{N}=190)$

\begin{tabular}{|c|c|c|c|}
\hline \multicolumn{2}{|l|}{ Survey items } & Number of respondents & Constituent ratio (\%) \\
\hline \multirow{3}{*}{ Attitude towards blending participation in teaching } & approval & 136 & 72.7 \\
\hline & not to matter & 40 & 21.4 \\
\hline & disapproval & 11 & 5.9 \\
\hline \multirow{5}{*}{ Be more effective to improve students' autonomous learning ability. } & blending participation & 97 & 51.9 \\
\hline & Problem-based Learning (PBL) & 47 & 25.1 \\
\hline & Thousand Questions Plan & 17 & 9.1 \\
\hline & Flipping classroom & 13 & 7.0 \\
\hline & be invalid & 13 & 7.0 \\
\hline \multirow{5}{*}{ Be more effective to improve the ability of teamwork. } & blending participation & 93 & 49.7 \\
\hline & Problem-based Learning(PBL) & 30 & 16.0 \\
\hline & Thousand Questions Plan & 18 & 9.6 \\
\hline & Flipping classroom & 37 & 19.8 \\
\hline & Be invalid & 9 & 4.8 \\
\hline
\end{tabular}


Be more effective in communication skills

Be more effective for the innovation ability of extracurricular practice.

Be more effective in analyzing and solving problems

Favorite teaching method

Whether it affects knowledge mastery and academic achievement

Impact on knowledge mastery and academic achievement

\section{B. Effectiveness of students' extracurricular practical innovation ability}

From Table 2 to 5, it can be seen that through blending participation classroom teaching, there were two provincial and three school-level innovative entrepreneurship training programs gained by approved university students. We have
Cont. to TABLE I.

\begin{tabular}{|c|c|c|}
\hline Blending participation & 88 & 47.1 \\
\hline Problem-based Learning(PBL) & 31 & 16.6 \\
\hline Thousand Questions Plan & 29 & 15.5 \\
\hline Flipping classroom & 30 & 16.0 \\
\hline Be invalid & 9 & 4.8 \\
\hline Blending participation & 90 & 48.1 \\
\hline Problem-based Learning(PBL) & 35 & 18.7 \\
\hline Thousand Questions Plan & 26 & 13.9 \\
\hline Flipping classroom & 21 & 11.2 \\
\hline Be invalid & 15 & 8.2 \\
\hline Blending participation & 96 & 51.3 \\
\hline Problem-based Learning(PBL) & 49 & 26.2 \\
\hline Thousand Questions Plan & 24 & 12.8 \\
\hline Flipping classroom & 9 & 4.8 \\
\hline Be invalid & 9 & 4.8 \\
\hline Blending participation & 92 & 49.2 \\
\hline Problem-based Learning(PBL) & 36 & 19.3 \\
\hline Thousand Questions Plan & 12 & 6.4 \\
\hline Flipping classroom & 19 & 10.2 \\
\hline not to matter & 13 & 7.0 \\
\hline other methods & 15 & 8.0 \\
\hline have & 136 & 72.7 \\
\hline not have & 23 & 12.3 \\
\hline not clear & 28 & 15.0 \\
\hline raise & 125 & 66.8 \\
\hline reduce & 15 & 8.0 \\
\hline no effect & 37 & 18.0 \\
\hline not completed & 10 & 5.4 \\
\hline
\end{tabular}

also won the third prize and two winning prize in the National Forum on Innovation in Basic Medicine and the Experimental Design Competition. Moreover, we have also won the first prize and the second prize and won the third prize fifth times in the Science and Technology Competition of the Challenge Cup. We published four papers and won one national utility model patent.

TABLE II. STUDENT INNOVATION AND ENTREPRENEURSHIP TRAINING PROGRAM FOR APPROVED UNIVERSITY STUDENTS FROM 2013 TO 2017

\begin{tabular}{|c|c|c|c|}
\hline Year & Project name & Project level & Grade and major \\
\hline 2013 & $\begin{array}{c}\text { Study on Environmental problems in Xiangyang } \\
\text { Hubei Province / Schools }\end{array}$ & $\begin{array}{c}\text { Innovation and Entrepreneurship training Project for college students in } \\
\text { medicine }\end{array}$ & $\begin{array}{c}\text { Grade 2011 clinical } \\
\text { Hubei Province / Schools }\end{array}$ \\
\hline 2015 & $\begin{array}{c}\text { The Design of the Three-dimensional Road Sign } \\
\text { in Xiangyang }\end{array}$ & $\begin{array}{c}\text { Innovation and Entrepreneurship training Procts in } \\
\text { Huber }\end{array}$ & Grade 2012 Nursing. \\
\hline 2017 & $\begin{array}{c}\text { Study on influencing factors of fine weather in } \\
\text { Xiangyang }\end{array}$ & $\begin{array}{c}\text { Innovation and Entrepreneurship training Project for college students in } \\
\text { Schools }\end{array}$ & Grade 2015 Nursing. \\
\hline
\end{tabular}

TABLE III. WINNER PRIZE OF THE 2014-2018 STUDENT SUBJECT COMPETITION

\begin{tabular}{|c|c|c|c|}
\hline Year & Project name & Project level & Grade and major \\
\hline 2014 & $\begin{array}{c}\text { Study on environmental problems of air and water quality in Xiangyang } \\
\text { City from } 2010 \text { to } 2012\end{array}$ & $\begin{array}{c}\text { Winning prize of the Third National Basic } \\
\text { Medical Innovation Forum and Experimental } \\
\text { Design Competition }\end{array}$ & $\begin{array}{c}\text { Grade 2011 clinical } \\
\text { medicine }\end{array}$ \\
\hline 2016 & $\begin{array}{c}\text { Relationship between air pollution and respiratory diseases in Xiangyang } \\
\text { in } 2015\end{array}$ & $\begin{array}{c}\text { Winning prize of the Fourth National Basic } \\
\text { Medical Innovation Forum and Experimental } \\
\text { Design Competition }\end{array}$ & $\begin{array}{c}\text { Grade 2013 clinical } \\
\text { medicine }\end{array}$ \\
\hline 2018 & $\begin{array}{c}\text { Comparative analysis and prevention and cure countermeasures -- the air } \\
\text { quality of the northern and the southern cities -- Tangshan and Xiangyang }\end{array}$ & $\begin{array}{c}\text { The Third Prize of the Fifth National Basic } \\
\text { Medical Innovation Forum and Experimental } \\
\text { Design Competition }\end{array}$ & $\begin{array}{c}\text { Grade 2015 clinical } \\
\text { medicine }\end{array}$ \\
\hline
\end{tabular}

TABLE IV. WINNER PRIZES OF THE SCIENCE AND TECHNOLOGY COMPETITION OF THE CHALLENGE CUP IN 2013-2019

\begin{tabular}{|c|c|c|c|}
\hline Year & Project name & Project level & Grade and major \\
\hline 2013 & Study on environmental problems in Xiangyang & $\begin{array}{c}\text { The second prize of the school's the Science } \\
\text { and Technology Competition of the } \\
\text { Challenge Cup }\end{array}$ & $\begin{array}{c}\text { Grade 2011 } \\
\text { clinical } \\
\text { medicine }\end{array}$ \\
\hline 2015 & Three-dimensional road sign design in Xiangyang & $\begin{array}{c}\text { The first prize of the school's the Science } \\
\text { and Technology Competition of the } \\
\text { Challenge Cup }\end{array}$ & $\begin{array}{c}\text { Grade 2012 } \\
\text { nursing. }\end{array}$ \\
\hline
\end{tabular}




\begin{tabular}{|c|c|c|c|}
\hline \multicolumn{4}{|c|}{ Cont. to TABLE IV. } \\
\hline 2015 & Relationship between air pollution and respiratory diseases in Xiangyang in 2015 & $\begin{array}{l}\text { The third prize of the school's the Science } \\
\text { and Technology Competition of the } \\
\text { Challenge Cup }\end{array}$ & $\begin{array}{l}\text { Grade } 2013 \\
\text { clinical } \\
\text { medicine }\end{array}$ \\
\hline 2017 & $\begin{array}{l}\text { Comparative analysis and prevention and cure countermeasures -- the air quality of } \\
\text { the northern and the southern cities -- Tangshan and Xiangyang }\end{array}$ & $\begin{array}{l}\text { The third prize of the school's the Science } \\
\text { and Technology Competition of the } \\
\text { Challenge Cup }\end{array}$ & $\begin{array}{l}\text { Grade } 2015 \\
\text { clinical } \\
\text { medicine }\end{array}$ \\
\hline 2019 & $\begin{array}{l}\text { Study on the association of AIDS patients and universal education and the spread of } \\
\text { AIDS }\end{array}$ & $\begin{array}{c}\text { The third prize of the school's the Science } \\
\text { and Technology Competition of the } \\
\text { Challenge Cup }\end{array}$ & $\begin{array}{l}\text { Class } 2016 \\
\text { clinical } \\
\text { medicine }\end{array}$ \\
\hline 2019 & $\begin{array}{l}\text { Study on the investigation of AIDS knowledge and health education strategies for } \\
\text { college students in Xiangyang. }\end{array}$ & $\begin{array}{l}\text { The third prize of the school's the Science } \\
\text { and Technology Competition of the } \\
\text { Challenge Cup }\end{array}$ & $\begin{array}{l}\text { Class } 2016 \\
\text { clinical } \\
\text { medicine }\end{array}$ \\
\hline 2019 & $\begin{array}{l}\text { Systematic evaluation and meta-analysis of short-term intensive treatment of basic } \\
\text { insulin in patients with type } 2 \text { diabetes mellitus }\end{array}$ & $\begin{array}{l}\text { The third prize of the school's the Science } \\
\text { and Technology Competition of the } \\
\text { Challenge Cup }\end{array}$ & $\begin{array}{l}\text { Class } 2016 \\
\text { clinical } \\
\text { medicine }\end{array}$ \\
\hline
\end{tabular}

TABLE V. STUDENTS’ PAPERS AND PATENTS FROM 2014 TO 2018

\begin{tabular}{|c|c|c|c|}
\hline Year & Project name & Project level & $\begin{array}{c}\text { Grade and } \\
\text { major }\end{array}$ \\
\hline 2014 & $\begin{array}{l}\text { Study on environmental problems of air and water quality in Xiangyang City } \\
\text { from } 2010 \text { to } 2012\end{array}$ & $\begin{array}{c}\text { Journal of The Fourth Military Medical } \\
\text { University }\end{array}$ & $\begin{array}{l}\text { Grade } 2011 \\
\text { clinical } \\
\text { medicine }\end{array}$ \\
\hline 2016 & Effect of particulate matter on Respiratory system Diseases in Xiangyang in 2015 & $\begin{array}{l}\text { Collected papers of the academic annual } \\
\text { meeting of the Chinese Society of } \\
\text { Environmental Sciences (2016) }\end{array}$ & $\begin{array}{l}\text { Grade } 2013 \\
\text { clinical } \\
\text { medicine }\end{array}$ \\
\hline 2017 & $\begin{array}{l}\text { Comparative analysis and prevention and cure countermeasures -- the air } \\
\text { quality of the northern and the southern cities -- Tangshan and Xiangyang }\end{array}$ & $\begin{array}{l}\text { Collected papers of the academic annual } \\
\text { meeting of the Chinese Society of } \\
\text { Environmental Sciences(2017) }\end{array}$ & $\begin{array}{l}\text { Grade } 2015 \\
\text { clinical } \\
\text { medicine }\end{array}$ \\
\hline 2018 & $\begin{array}{l}\text { The influence of motor vehicle ownership on good days in Xiangyang from } 2014 \\
\text { to } 2016 .\end{array}$ & $\begin{array}{l}\text { Collected papers of the academic annual } \\
\text { meeting of the Chinese Society of } \\
\text { Environmental Sciences (2018) }\end{array}$ & $\begin{array}{c}\text { Grade } 2016 \\
\text { clinical } \\
\text { medicine } \\
\end{array}$ \\
\hline 2016 & An intelligent road sign indicating device & national utility model patent & $\begin{array}{c}\text { Grade } 2012 \\
\text { nursing. }\end{array}$ \\
\hline
\end{tabular}

\section{Discussion}

\section{A. Improvement of blending participation teaching in students' practical innovation ability}

Through seven years of blending participation teaching research and practice and the effective organization of teachers, actively participating in active learning, carrying out classroom revolution and so on, students' autonomous learning ability and practical innovation ability have been effectively improved. The students have a total of 2 provincial-level and 3 school-level training programs for the innovation and entrepreneurship training program of the university students; they won the third prize and two winning prize of national basic medical innovation forum and the experimental design competition, etc. Moreover, the students published 4 papers and won 1 patent for the national utility model.

\section{B. Key elements in the implementation of blending participation teaching}

\section{1) Teachers organize carefully}

The person in charge of the course should constantly learn advanced teaching methods and ideas, and conscientiously study the teaching content; moreover, they should do a good job in the top-level design, formulate the reform learning plan and implementation path, and focus on standardizing the learning mode, student grouping, learning content after class, classroom learning participation form, curriculum assessment and so on.

\section{2) Active participation of students}

We should fully mobilize the enthusiasm and initiative of students to participate in classroom teaching, and tap their endogenous potential and motivation. Students can study the assigned learning content independently in the form of group, and consult the literature before class, so that to prepare for questions and cases, and to arrange sitcoms and so on.

\section{3) Take the form of a division classroom}

The participation of teachers and students can effectively coordinate the relationship between teaching and learning. In the first class, the teacher first introduces the knowledge, ability, quality and innovative teaching objectives of the course, and then each group selects 1 or 3 representatives to introduce the classroom cases and problems, the group members and other students participate in the classroom analysis and discussion. The report form can take the form of slide report, sitcom, participating lecture, keynote speech, discussion, etc., which can be presided over by the team leader. The second class is explained by the teacher in combination with the teaching content of the course, and it guides the problems raised by the students and the existing differences, carrying on the deepening understanding of the knowledge and unifying the curriculum content and the innovation goal, etc. More than that, the standard guides students to participate in extracurricular innovation practice.

\section{4) Problem-orientation}

Each student is involved in asking questions, and students' representatives summarize the questions for classroom reporting and discussion. The report includes the PPT report of 
the learning content, the relevant videos reviewed, the personal description of the case, the answers and discussion of the questions, the thinking of the online learning, and the personal opinions on the social problems, etc. In the discussion, the team leader interacts and questions between the students, and let them participate in the students to express their own views, correcting and guiding of the teachers in time for the misunderstandings. As a result, students have a high degree of participation, and the classroom atmosphere is active and warm. In the course of the teacher's focus, we should combine the students' questions and important knowledge points, answer the questions to the students, and further expand the scope of the students' participation in the discussion.

\section{5) Evaluation of teaching effect}

We will make a questionnaire on the effect of classroom teaching on the mobile phone. In the last class before the end of the course, the students will answer the questionnaire through the mobile phone. The results of questionnaire survey show that $72.7 \%$ of the students are in favor of the blending participation teaching reform, especially the active students strongly demand that this form should be adhered to, which is very helpful to cultivate students' autonomous learning ability, communication ability, teamwork ability, problem solving ability, extracurricular practice innovation ability and the knowledge mastery and academic achievement.

6) Improvement of classroom discipline in mobile-free classes

Each class teacher reminds students to turn off their mobile phones and put them in their schoolbags or pockets before class. When they need to use their mobile phones, they are reminded to take out their mobile phones. In the teaching of students, teachers carry out classroom inspections, check students' learning status, and bring teaching materials and so on. The teacher conducts the examination of class attendance, announces the assessment regulations before the class, lists the class discipline in the performance assessment, handles the performance assessment for those who do not attend the attendance or violates the class discipline, and evaluates the attendance status of the attendance through random name and questions, etc. Teachers can reduce the scores of late students and absenteeism students according to the regulations, so the classroom discipline is good, and the classroom attendance rate is above $99 \%$.

\section{Improvement measures}

In the future, we should further refine the measures and paths of blending participation teaching reform, improve students' ability to ask problems, and solve problems and participate in practical innovation. Moreover, we should implement small class teaching, carry out group learning, reduce the number of groups, and ensure that each student has the opportunity to participate so that to improve the coverage of participating students by $100 \%$. Teachers need to combine students' autonomous learning, classroom participation and teachers' teaching guidance organically. Further, they should clearly define the time for students to participate in lectures and discussions, and improve learning efficiency and master knowledge ability within a limited time. Through classroom revolution to cultivate students' innovative ideas, we can stimulate students to participate in practical innovation, and help students to be applied innovative medical talents in China at an early date.

\section{CONCLUSION}

(1) Students approve to the blending participation teaching (72.7\%) and this is the most popular teaching method of the students.

(2) Blending participation teaching effectively improved students' autonomous learning ability (51.9\%), teamwork ability (49.7\%), communication ability (47.1\%), and problem solving ability (51.3\%), and extracurricular practical innovation ability (48.1\%), etc.

(3) Blending participation teaching promotes the achievement of the practice innovation of the students.

\section{REFERENCES}

[1] Sun Lin, Chen Mengqi. The Practice and Exploration of Participation Teaching in Colleges and Universities. Agricultural Education in China. 2017, 4:40-45

[2] Yu Miao. A Probe into Participation Teaching and the Cultivation of College Students' Innovative Ability: A Case Study of Management Course. Curriculum of Education Research. 2017, 48:24-25

[3] Lu Jianfei, Lai Haoming. Take The Participation Teaching As The Motive Force, Improves The Classroom Teaching Quality. Scientific and Technological Wind. DOI:10.19392/j.cnki. 1671-7341. 2016180172, 196-197

[4] Liu Qiuting, Tu Ewen, Tan Li. Discussion on Participatory Teaching Method in Neurology Course Teaching. Chinese Modern Doctor 2016 54 (25): 118-121.

[5] Li Jun, Sun Weiquan. Reform and Practice of Preventive Medicine Teaching Mode in the Cultivation of Applied Clinical Medical Talents. Journal of Hubei University of Arts and Sciences. 2014, 35 (2): 82.85

[6] Dong Yinguo. Participatory Approach: Cultivate Active Learning And Create An Important Ladder of Learning. Higher Education in Chemical Industry. 2018, 2: 81-85 